\title{
構造材料の寿命と信頼性
}

1. 緒

言

構造材料の破損や故障の発生, ひとたびそれが発生し てからの破損防止などに関連して，主として確率過程論 的取扱いについて解説する．例示としては，金属材料に 関するものが多いが，考え方と取扱い方は高分子材料そ の他の材料にも共通している．なお，確率過程論的取扱 いに関しては文献1)にて採り挙げた構想と内容，更にそ の後の新しい研究成果を織り込んでまとめた。

\section{2. 確率過程の問題としての取扱い}

固体破壊の分野に対する確率過程論の応用は，主に強

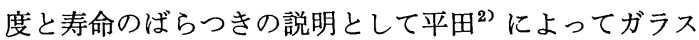
の静荷重による破壊に対して提案されたといってよく, そのあと引き続いて横堀たち ${ }^{324)}$ によって，主として金 属材料の疲労破壊(512)15)16)，クリープ破壊(2)(17)，ぜい性

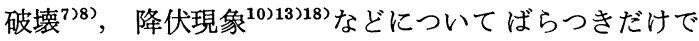
はなく, 一般的に材料強度 ${ }^{1334)}$ と破壊の問題にわたって 一連の系統的展開が行われた（破壊問題の形式的速 度 過 程型の取扱いの歷史は，それより若干古いが，これらは 明白に一-explicitに一確率過程の問題として採り挙 げたということではないようである)，その後，高分子 材料 ${ }^{1920)}$ やコンクリート ${ }^{211}$ についても調べられている.

ここに述べる確率過程論そのものは統計力学の基盤を

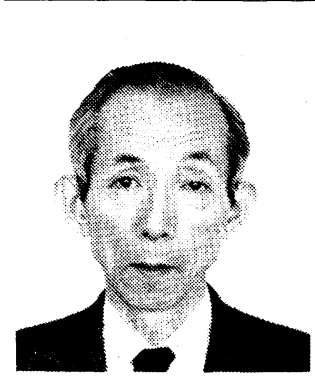

$*$ 東北大学名誉教授 $\cdot$ 工学院大 学教授 (自宅 $\mathbf{T} 982$ 宮城県 仙台市青山 1-31-15) 昭和16 年東京帝国大学工学部卒業. 東京大学航空研究所啒託, 理 工学研究所技官, 東北大学工 学部助教授を経 $て$, 昭和32年 東北大学工学部教授. 昭和 56 年より現在に至る. 国際材料 破壊学会創設会長. 日本学士 院賞受賞. 米国アカデミー外 国人会員. 著書に「材料強度 学 3 巻」など。

\section{横 堀 武 夫*}

なしており，その応用は原子核の崩壊の問題など物理学 のいくつかの分野にわたっている．近年になっては，工 学分野においても情報工学, 信頼性工学など, 更に生物 学, 医学及び経済学の分野にまで広範囲に及んでいる.し かしこれら工学分野への応用のらちでは, 上記，材料強 度と破壊への適用が歷史的には早かったようである225)。

\section{3. 固体破壊の確率過程論}

いま，ある材料からなる多数の試験片（いずれも同一 物とみなし得る)の集団が存在するとしよう。このいず れにも別々に等しい一定の応力 $\sigma$ を同時に負荷したと考 えてみる．応力を充分大きくとっておくと，一般にある 時間の後に破壊が起こるであろう。しかし，この試験片 全部が同時に破壊するといらのではなく，負荷開始後破 壊までの時間はある範囲にばらつくであろう。ここでは 試験片に一つのき裂が発生すれば最終の破壊に導くもの と考えておく. 負荷の瞬間を時閒の原点にとり, 時刻 $t$ まで破壊が起こらず次の微小時間 $d t$ 内に，すなわち， $t$ と $t+d t$ の間にき裂が発生する確率(遷移確率)を $m(t)$ $d t$ とする. *1

一般にこの遷移確率 $m$ は外力としての応力 $\sigma$ と時間 $t$ の関数である. 外力は局所応力 $\sigma_{l}$ としての効果をもつ のであるから，

$$
m=f\left(\sigma_{l}, t\right)
$$

のように表わされる，き裂の存在する場合にはその近傍 では $\sigma_{l}$ の尺度として応力拡大係数 $K(\equiv \alpha \sqrt{\bar{a}} \sigma)$ を用い ればよい.ここで $a=$ き裂長さ， $\alpha=$ 無次元数值.さて 式(1)における時間 $t$ の効果は温度などを含めて環境によ る材料全体の時間的変化，またき裂を有するときはその 近傍の領域の時間的変化などにきいてくる. 個々の問題 の解析に対しては式(1)で表される一般的な考え方を基本 とすればよい，例えば環境による破壊は，式(1)の考え方

*1 以下には混同をさけるため, 遷移確率としては単位 繰り返し数当たりについては $\mu$ ，単位時間当たりについ ては $m$ なる記号で表わすことにする. 
で整理される。

しかし, 温度を含めて環境の影響の少ない場合には式 (1)内の $t$ の効果は小さいと考えられる. そこで 3 章で は,まず,

$$
m=f\left(\sigma_{l}\right)
$$

なる場合の取扱いを述べることにする.

$t$ まで破壊せずにいる試験片の総数を $N(t)$ とすれば, $t$ と $t+d t$ との間に破壊する試験片の数, すなわち- $d N$ は,

$$
-d N=N(t) m(t) d t
$$

なる関係で表わされる. 時間の初めにおける試験片全数 を $N_{0}$ とすれば，式(3)から

$$
-\frac{d N}{N_{0}}=\frac{N(t)}{N_{0}} m(t) d t
$$

ここで $N(t) / N_{0}$ は, 時刻 $t$ まで破壊が起こらない確率 を表わしているので，これをPなる記号で表わすと*2, $-d N / N_{0}=-d P$ と書ける。 $-d P$ は時刻 $t$ と $t+d t$ との 間で試験片が破壊する確率を表わしている.このように して式(3)は次のように書き変えられる.

$$
-d P=P(t) m(t) d t
$$

式(5)は式(3)と同じである. 破壊が $t$ と $t+d t$ の間で発 生する確率, すなわち頻度分布を $q(t) d t$ で表わすと

$$
q=-\frac{d P}{d t}
$$

なる関係があり，また $P$ の定義から次の関係がある.

$$
\begin{aligned}
& P(t)=\int_{t}^{\infty} q(t) d t \\
& P(0)=1
\end{aligned}
$$

実験的には，ヒストグラム $q(t)$ から式(7)によって $P(t)$ を求め, この $P(t)$ から式(5)にしたがって

$$
\frac{d \log P}{d t}=-m(t)
$$

によって $m(t)$ の時間的変化を求めることができる. す なわち, $m$ は $\log P-t$ 曲線の勾配から求められる. $P=t$ まで破壊しない確率.

(1) $m$ が $t$ に無関倸の場合，このときは式(5)から

$$
\begin{aligned}
& P d t=\exp (-m t) d t, \\
& q d t=m \exp (-m t) d t
\end{aligned}
$$

また平均時間(破壊までの) $\bar{t}$ は

$$
\bar{t}=\int_{o}^{\infty} t q d t=\int_{o}^{\infty} t m \exp (-m t) d t=\frac{1}{m}
$$

となる. すなわちこの場合はポアソン分布に従い, $t$ と $t+d t$ 時間内に破壊する試験片数はそれまでに破壊しな いでいるものの数に比例する.

*2 信頼性工学では破壊確率の記号として $P$ を用いるこ とがあるので混同しないように注意する。
(2) $m$ が時間の関数として変化する場合. 一般に $m$ が 時間の関数のときは式(5)を積分して

$$
P(t)=\exp \left(-\int_{o}^{t} m d t\right)
$$

また式(6)を用いて

$$
q(t) d t=m \exp \left(-\int_{o}^{t} m d t\right) d t
$$

さて, 普通の引張試験のように荷重速度がほぼ一定と 考えられるような場合の例として, 応力速度 $\dot{\sigma}$ が一定の 場合を考えてみる.すると任意の時刻における応力は,

$$
\sigma(t)=\dot{\sigma} t
$$

となるから，

$$
m=f(\dot{\sigma} t)
$$

と表わされる.

式(14)の関係を式(13)に代入して $\dot{\sigma}$ で表わせば, 強度 の頻度分布は

$$
g(\sigma) d \sigma=\frac{m}{\dot{\sigma}} \exp \left(-\frac{1}{\dot{\sigma}} \int_{o}^{\sigma} m d \sigma\right) d \sigma
$$

となる. いわゆる強度 $\sigma_{m}$ としてこの分布の最頻值を考 えれば, $\sigma_{m}$ は

$$
\partial g / \partial \sigma=0
$$

又は,

$$
\frac{\partial g}{\partial t}=0
$$

から求められる. 式(13)を用いると式(18)から

$$
d m / d t=m^{2}
$$

なる関係を得る ${ }^{3)}$. 式(19)を充す時刻 $t_{m}$ に対する $\dot{\sigma} t_{m}$ とし て $\sigma_{m}$ が求められる. $\sigma_{m}=\dot{\sigma} t_{m}$ を式(19)に代入すれば

$$
\dot{\sigma}\left|\frac{d f(\sigma)}{d \sigma}\right| \sigma_{m}=f^{2}\left(\sigma_{m}\right) \text {. }
$$

\section{4. クリープ破壊}

3 章の式(2)では負荷応力が, 時間とともに変化するこ とによって $m$ が時間的に変化する場合の例を取扱った. 他方, 一定応力ないし一定荷重下で断面積の変化がほと んど起こらない場合, すなわちクリープ破壊の場合につ いて考えてみる，典型的例を図 2 (a)，(b)，(c)に示す.す なわち, $m$ は負荷直後時間とともに次第に増し，ほぼ一 定值をとってから，ついに増加していく.

更に， 3 状態 2 段の確率過程として例えば，最初の状 態を状態 1 , 加速クリープ発生を状態 2 , 破壊すること を状態 3 として解析が行われている ${ }^{1758)}$. 破壊までの全 寿命を $t$ とし, 加速クリープ発生までの時間を $t_{1}$, その あと破壊までの時間を $t_{2}$ とする.すなわち,

$$
t=t_{1}+t_{2}
$$

のように分けて, 時間 $t_{1}$ と $t_{4}$ を測定した結果, 測定值 $t_{1}$ 


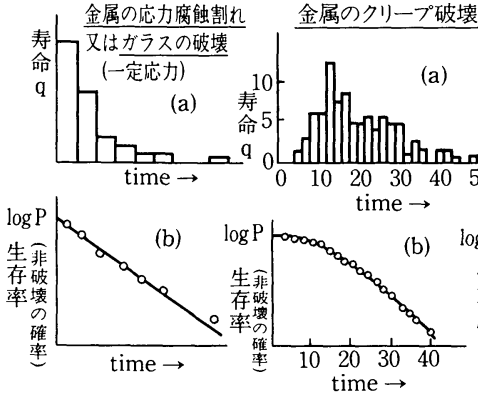

機器·生物·人間

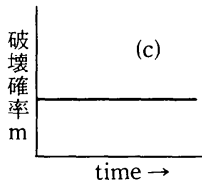

図 1

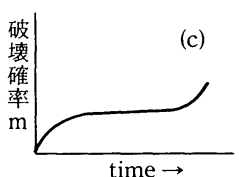

図2*
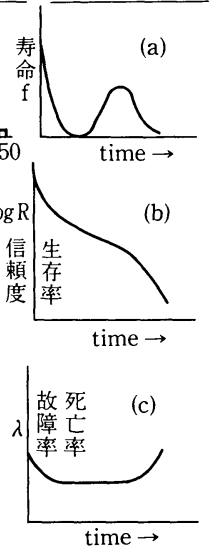

図 3
* 金属の疲労破壊では横軸 $\mathrm{t}$ の代りにNを用いればよい

図 $1 \sim 3$ 材料強度の確率過程論と信頼性工学の基 本概念の対比

と $t_{2}$ のばらつきの相関性のないことがたしかめられてい る ${ }^{17)}$. これらのことから, 全過程は熱活性化過程として の少なくとも二つの確率過程からなりたつものと考えた ほうがよい。

全寿命をき裂又は damage 発生までの過程の寿命と, その伝ぱから最終破壊までの過程の寿命とからなるとし

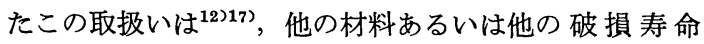
(疲労寿命, 応力腐蝕割れ寿命)などにも適用される.

\section{5. 疲 労 破 壊}

疲労破壊は本来, 時間的現象であるから，この意味か らも運動論 (kinetic theory) 的にとらえねばならない.
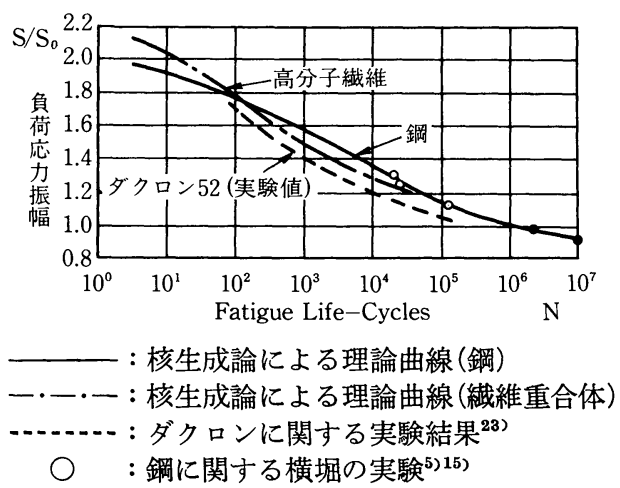

$S_{0}=10^{6}:$ 回絽り返し数に対する疲労強度

図 4 金属材料と高分子材料の応力・疲労寿命関係 特性の比較 ${ }^{22}$
特に疲労寿命についてはそうでなければならない，その 機構を調べる基本として確率過程論的考え方が必要とな る. 疲労破壊の場合には時間 $t$ の代わりに繰り返し数 $N$ を用いればよい，平滑材(切欠きや巨視き裂をもたない 材料)の場合には，き裂の発生過程が破壊の律速となる 場合が多く，そのような場合の結果は図 2 (a), (b), (c) と 同様な傾向を示している．このような平滑材において， 核生成論的取扱いが実験とよく一致する場 合を示す ${ }^{22}$ (図 4 )。横堀のこの取扱いを高分子繊維材にほとんどそ のままPrevorsek ら ${ }^{23)}$ が適用して，実験結果とよく一致 することを示している. 図 4 にはこれら高分子材の寿命 を $10^{6}$ 繰り返し数の寿命に当たる疲労強度 $\left(S_{0}\right)$ で規格化 して示したが，金属材料も高分子材料もほぼ同一の曲線 上にのることがわかる.

\section{6. 疲労き裂伝ぱ}

切欠きや巨視き裂をもつ材料の疲労では，その切欠き やき裂の成長過程が律速となる場合が多く，このような 場合には，疲労き裂成長の核生成論 ${ }^{24) ~ 28)}$ 及び転位群 の

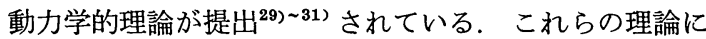
おいては, 律速過程としての確率過程模型として次の A とB との 2 とおりの考え方及びそれを組合せた考え方が とられる.

型式 $(\mathrm{A})$ ：き裂の伸長は繰り返しごとに(サイクルごと に）抗このではなくて，伸長自身が確率過程であると 考える ${ }^{24)}$. 疲労破壊のような場合には破壊まで $n+1$ 状 態， $n$ 段確率過程であると考えたほうがよい. すると疲 労き裂の伝ぱの繰り返し数 $N$ に対する様相，すなわち， き裂半長 $a$ の $N$ に対する増加の様相は図 5 のような不連 続曲線になると考えてよい. 疲労き裂成長のミク口機構 としては，いずれの型式に従うとしても次のような取扱 いが可能である ${ }^{24)}$. 図 3 からわかるように

$$
\frac{d a}{d N}=\frac{d a}{d n} / \frac{d N}{d n}
$$

と表わすことができる. 一方，各段階に主き裂が伸長す

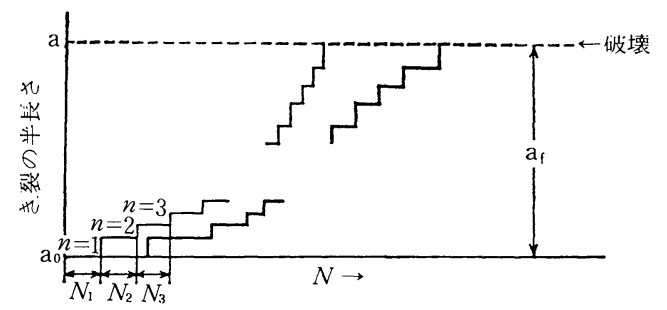

図 $5 n+1$ 状態, $n$ 段確率過程としての疲労き裂の 伝ぱ24) 
る半長さは繰り返し数によらないとしてこれを $\varepsilon_{A}$ とす ると

$$
\frac{d a}{d n}=\varepsilon_{\boldsymbol{A}}
$$

となる。また，一般に $i$ 番目の段 (step) では

$$
\frac{d N}{d n}=\bar{N}_{i}
$$

である。式(22)，式(23)を式(21)に代入すると

$$
(d a / d N)=\varepsilon_{A} / \bar{N}_{i}
$$

ところで式(11) 及び 3 章はじめの脚注より $\bar{N}_{i}=1 / \mu_{i}$ の関 係があるから式(24)に， $\mu_{i} \equiv \mu_{A}$ なる記号を用いて $\bar{N}_{i}=$ $1 / \mu_{\boldsymbol{A}}$ を代入すると

$$
\frac{d a}{d N}=\varepsilon_{A} \mu_{A}
$$

のよらに表わされる. ここで $\mu_{A}=$ サイクル当たりの遷 移確率である.ささて, 疲労き裂のミクロ機構がどのよう なものであっても ${ }^{24) ~ 31), ~}$

$$
\mu_{A}=M_{f} \Delta K^{\delta f 8}
$$

のように表わされることが多い. $M_{f}^{\delta f}$ は常数.

型式 (B)：き裂の伸長は繰り返し(サイクル)ごとに 1 対 1 の関係でかならず起こるが，繰り返しごとの伸長量 $\varepsilon_{B}$ それ自身のほうが確率過程論的平均值であると考える ${ }^{29)}$ 〜31). すると $d a / d N$ は

$$
\frac{d a}{d N}=\varepsilon_{\boldsymbol{B}}
$$

で表わされる．例えば，金属の場合は 図 6 の型式 II-(e) の模型に従うときは，すべりによるき裂端の単位サイク ル当たりの鈍化 (blunting) ないし，ずり (off-set) 量 $\varepsilon_{B}$ は，単位サイクル当たり，き裂先端から射出される転位

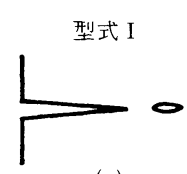

(a)

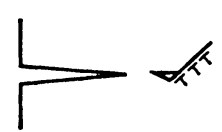

(b)

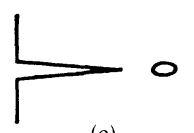

(c)
型式 II

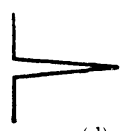

(d)

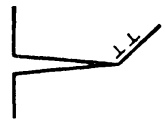

(e) (a) : 型式 I -1，(b)：型式 I -2, (c) : 型式 I -3,

(d) : 型式 II-1，(e)：型式 II-2

図 6 疲労き裂先端伸長のミクロ機構の各種模型の 基本概念 ${ }^{31}$
の数そに比例すると考えられる.すなわち，

$$
\varepsilon_{B}=b z
$$

ここで $b=$ バーガースベクトル（結晶転位強度ベクトル）， 他方, き裂端からの転位群の射出といら複合確率過程と して求めた $z$ は，単独転位の移動の場合の定数倍の見掛 けの活性化エネルギーをもつ一つの速度過程の形で表わ される ${ }^{29) ~ 31)}$. この速度過程の速度を $\mu_{B}$ と表わせば， $z$ は $\mu_{B}$ に比例することになる.すなわち，

$$
\varepsilon_{B}=\lambda_{l} \mu_{B}
$$

のように表される.ここで $\lambda_{l}=$ 比例定数. したがって型 式(A)の場合と同様に(25)式を得る.

型式 $(C)$ : 型式 $(A)$ と型式 $(B)$ の混合型式 型式 $(A)$ と 型式 (B)を組合せた考え方も可能である．また，そのほ らが一般的である。この混合型式のうちで考えられる模 型は，型式 (B)において，ずりの生起が決定論でないと いら型式である。そのときは，型式 (B)における式(27) の $\varepsilon_{B}$ に毎サイクル当たり, ずりの生起する確率をかけ てやればよい.

\section{7. 材料疲労寿命は繰り返し数によって決ま るのか，時間によって決まるのか}

材料の疲労破壊になぜ繰り返すことが必要なのかとい う命題に対する解答が，疲労が他の型式の破壊と根本的 に異なることの解明の鍵である ${ }^{32)}$. しかし，この研究は きわめて少ない. 例えば次の例をとればわかるであろう. 室温にて一定応力振幅の繰り返し応力をある繰り返し数 だけ与えた後, その振幅に等しい一定応力を負荷して クリープ試験を行っても長期にわたって破壊が起こらな いにも拘らず，再びさきの同一の応力振幅で繰り返し応 力を加えると数回〜数十回の繰り返し応力のもとで，た だちに破壊が生ずるといら実験を昔著者が行ったことが ある ${ }^{33)}$.この例からわかるように室温における疲労寿命 は，時間に依存するにしても繰り返すことによって大き く左右されることを示している. 他方, 高温では; 疲労 寿命は繰り返し数ではなく，時間によって大きく左右さ れる ${ }^{34)}$. このようにして疲労破壊寿命は一般に条件によ って, 繰り返し数にも時間にも左右されることがわか る.しかし，この挙動の詳細な機構はまだ詳細に解明さ れていない.

一定応力下での熱活性化過程(例えば速度過程)に従う 破壊の寿命 (時間で表した) $t_{f}$ は, 式(11)から式(30)で表 わされる。

$$
t_{f}=1 / \mu
$$

したがって，疲労破壊が時間だけできまるならば，式 
(30)が適用されるから，寿命 $t_{f}$ は繰り返し速度 $f$ に無 関係に時間だけできまることになる。繰り返し速度 $f$ と 破壊寿命(繰り返し数で表した) $N_{f}$ とは

$$
N_{f}=f t_{f}
$$

なる関係にあるから， $f$ がことなれば繰り返し数で表 した疲労寿命 $N_{f}$ がことなるだけである. $t_{f}$ の方は $f$ に 無関係でこのことは，室温などにおける実験と矛盾する ことになる. 本問題に対する解答としては浴の二つの考 え方が提出されている.

(1) 絽り返しによる準備期間の概念

き裂発生ないし伸長開始のためには，潜在期間として ある数の繰り返し数が必要であるといら考え方である.

これによると，核生成論 35 模型に基ゔいて破壊寿命 $t_{f}$ は “ $f$ にも”依存することになり，すなわち，疲労寿命は 時間 $t$ だけでは決まらないことになる。すなわち，

$$
t_{f}=t_{0}+\left(N_{i} \mid f\right)
$$

ここで, $t_{0}, N_{i}$ は $f$ に無関係.

他方，この考え方は模型として核生成論でなければな らないことはない，例えば，疲労き裂伸長のしきい応力 拡大係数に対しては，転位の運動への摩擦抵抗の減少を 生起させるために準備繰り返し数が必要であるという模 型で説明 ${ }^{37) 38) さ れ る . ~}$

(2) 繰り返しの決定論模型

この模型は繰り返しについて決定論的模型である。 す なわち, 繰り返すといらことが律速過程の前提条件とし て必要であるが，毎サイクル内で，その過程が時間依存 型なのである，例えば，この概念は疲労き裂成長の転位 群の動力学理論 ${ }^{29330331)}$ において展開されている.

\section{8. 遅れ破壊 (応力腐蝕割れ)}

周囲をとりかこむ各種侵蝕性雾囲気ないし環境下で一 定応力のもとで起こるいわゆる遅れ破壊(断面積がほと んど変化しない)は，同様に確率過程として考えること ができる ${ }^{6}$. その後に高力鋼 $(0.9 \% \mathrm{C}$ 鋼) の水素ぜい性 遅れ破壊に応用され ${ }^{392}$ ，この種破壊の破壊時間のばらつ きの説明が行われている ${ }^{39740)}$. この場合にはガラスの破 壊の項で述べたように，クリープ破壊も遅れ破壊も時間 依存型の破壊であり，多状態多段の確率過程として考え ねばならない， 6 章に述べた考え方は繰り返し数 $N$ と時 間 $t$ との適当な換算と対応を検討することによって，そ のまま適用される ${ }^{411}$. このときは遷移確率を $m_{d}$ とすれ ば 6 の $(\mathrm{A})$ と同じ取扱いによって

$$
\begin{aligned}
& \quad \frac{d a}{d t}=\varepsilon_{d} m_{d} \\
& \text { ここで }
\end{aligned}
$$

$$
m_{d}=M_{d} K^{\delta_{d}}
$$

なる式で表される。 $K=\sqrt{\overline{\pi a}} \sigma$ ，例えば遅れ破壊むでの 寿命 $t_{P}$ は

$$
t_{P}=\cdot \frac{1}{A_{I I} \sigma^{2}}\left[\frac{1}{K_{I i}{ }^{\delta d-2}}-\frac{1}{K_{\mathrm{fscc}}{ }^{\delta d-2}}\right]
$$

の上らに与えられる ${ }^{41}$. ここで, $K_{1 i}=\sqrt{\bar{\pi} a_{i} \sigma}, \sigma_{i}=$ 初期 き裂長さ， $K_{\mathrm{fscc}}=\sqrt{\bar{\pi} a_{f}} \sigma, a_{f}=$ 破壊時のき裂長さ，この ような理論の結果は実験結果をかなりよく説明すること ができる ${ }^{411}$.

\section{9. 一方向一回負荷による破壊 ${ }^{11)}$}

ここでは，いわゆる静的破壊の場合を考える．2 状態 1 段確率過程として考える. 普通の引張試験の場 合に は, 応力速度 $\dot{\sigma}$ を一定であると考えると, $\sigma$ は式(14)で 表わされるよらに時間とともに变化する. 一方, 遷移確 率としては核生成論 ${ }^{24)}$ 28) の立場から得られる核生 成 速 度 $r$ を用いる。他方， $r$ は

$$
r=L \sigma^{\delta}
$$

なる式で与えられる ${ }^{24) ~ 28)}$. ここで $L$ 及び $\delta$ は材料によ る定数. 式(36)に式(14)を代入すると

$$
m \equiv r \equiv L(\dot{\sigma} t)^{\delta}
$$

の上うに表わされる. 式(37)を式(12)に代入し， exp の

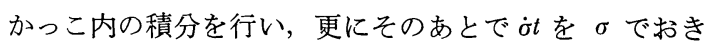
かえると，

$$
P(\sigma)=\exp \left(-\frac{L}{(\delta+1) \dot{\sigma}} \sigma^{\delta+1}\right)
$$

のように表わされる，あるいは，破壊強度が $\sigma$ 以下であ る確率, 寸なわち破壊強度の分布関数 $D(\sigma)$ は

$$
D(\sigma)=1-\exp \left[-\frac{L}{(\delta+1) \dot{\sigma}} \sigma^{\delta+1}\right]
$$

となる，破壊強度の頻度分布 (確率密度) 関数 $q$ は式(6)の 関係から

$$
q d \sigma=\frac{L}{\dot{\sigma}} \sigma^{\delta} \exp \left(-\frac{L}{(\delta+1) \dot{\sigma}} \sigma^{\delta+1}\right) d \sigma
$$

式(40)と後で述べる式(50)及び式(39) と式(51)をそれ ぞれ比べてみると全く同じ関数形であることがわかる. ただし， $L /(\delta+1) \dot{\sigma}$ が $\beta$ に, $(\sigma+1)$ が $m$ に相当している ことを注意したい.すなおち, ぜい性固体破壊の確率過 程理論はその中に Weibull の極值論による結果を $\dot{\sigma}=$ 特 定值, 温度=特定値という特別の場合として形式的に含 むことがわかる。

式(19)に式(37)を代入すると最頻值としての破壊強度 $\sigma_{c}$ は式(41)で与えられる.

$$
\sigma_{c}=\left(\frac{\delta \dot{\sigma}}{L}\right)^{1 /(\delta+1)}
$$


平均值としての破壊強度 $\bar{\sigma}_{c}$ は式(40)を用いて

$$
\sigma_{c}=\left[\frac{(\delta+1) \dot{\sigma}}{L}\right]^{1 /(\delta+1)} \Gamma\left(\frac{\delta+2}{\delta+1}\right)
$$

のように表わされる. $L$ は容積 $V$ に比例しているから上 の二つの式は容積効果をも表わしている.

巨視的応力集中源が分布する場合にも式(37) (42) と 全く同型式の式が得られることは，10章に述べる.

切欠き鋼材の平面ひずみぜい性破壊が一点の最大引張 応力では決まらないことが確かめられている ${ }^{42)}$. しか も，ある容積についての $\sigma^{\gamma}$ ( $\gamma=$ 定数)の積分值一定とい らクライテリオンによってきわめてよく実験と一致する ことがしめされている ${ }^{43)}$. このクライテリオンは式(37) 〜式(41) と一致し, 物理的, 力学的意味が本節の内容で 与えられる.

\section{0. 巨視的応力集中の不規則分布を考慮し た(破壊) 強度の確率過程論—ミクロと マクロを結合した強度の確率過程論}

9 章では原子ないし分子の熱振動のみを，いってみれ ばミクロ的不規則因子による確率過程として取扱った.

しかし，実際の材料や固体には結晶粒大きさ，各種非金 属介在物, 各種巨視的き裂型欠陥による応力集中も不規 則に分布しているわけである。 そこで，これらき裂型欠 陥ないし材料，組織の不均一性に基づく応力集中度がい ろいろな值に分布している場合，才なわち，9章におけ るミクロ不規則因子とこのようなマクロ的不規則因子と の双方をとり込んだ確率過程としての取扱いが次のよう に行われている ${ }^{44)}$ (図 7 )。

き裂半長 $a$ の確率密度関数を $f(a)$ とする. 試験片に 含まれているき裂の総数を $n$ (密度は一定)とし，おのお のの長さを $a_{1}, a_{2}, \cdots \cdots a_{n}$ とする（ $i$ 番目のき裂について

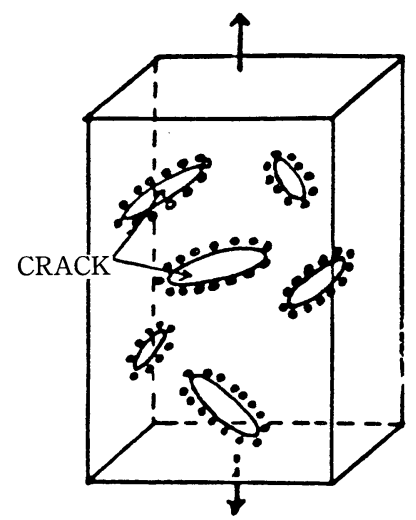

図 7 微視及び巨視的変動因子を含む材料 ${ }^{322}$
2 状態 1 段過程と考えている.). 時刻 $t$ まで試験片その ものとして破壊しない確率 $P$ とすれば，これは $n$ 個のき 裂のいずれからも破壊がおこらない確率にひとしいから

$$
\begin{gathered}
P(t)=\exp \left(-\int_{o}^{t} m_{1}(t) d t\right) \exp \left(-\int_{o}^{t} m_{2}(t) d t\right) \cdots \exp \\
\left(-\int_{o}^{t} m_{n}(t) d t\right)=\exp \left(-\int_{o}^{t} \sum_{i=1}^{n} m_{i}(t) d t\right)
\end{gathered}
$$

一方, 試験片について 2 状態 1 段階過程と考え, 試験片 そのものの遷移確率を $m(t)$ とすると式(9) が成り立つ. そこで式 (43) と式 (9) とを等しいとおくことにより式 (44)を得る44).

$$
m(t)=\sum_{i=1}^{n} m_{i}(t)
$$

$m_{i}$ したがって $m(t)$ は $a$ の関数であるから, $m(t)$ は試 験片ごとにことなる．すなわち， $m_{i}$ なる確率変数 (偶然 量)の $n$ 個の和の分布を求める問題に帰着する.

(i) 分布き裂総数 $n$ がきわめて多い場合 (実際の 場 合 は多くの場合これに近い) :このときには， $m_{i}$ の值とし て，近似的に試片ごとの平均值

$$
\bar{m}_{i}(t)=\int_{o}^{\infty} m_{i} g\left(m_{i}\right) d m_{i}=\int_{o}^{\infty} m_{i} f\left(a_{i}\right) d a_{i}
$$

を用いることができる ${ }^{44)}$. ここで $g\left(m_{i}\right)$ は試片ごとの $m_{i}$ の值の確率密度関数である. すると $\bar{m}_{1} \cdots \cdots=\bar{m}_{i}=\cdots$ $\cdots=\bar{m}_{n}$ である。 また，このときは試験片としての遷移 確率 $m$ も平均值 $\bar{m}$ を用いてもよい. 寸ると式(44) から

$$
\bar{m}(t)=n \bar{m}_{i}(t)
$$

$m_{t}$ は応力 $\sigma$ に対して (36) 式の形をもつから，この式を (45)式に代入し, 得られた $\bar{m}_{i}(t)$ を式(46)に代入すると,

$$
\bar{m}(t)=L_{0} \sigma^{\delta}
$$

にて表される.ここで，

$$
L_{0}=n K A R
$$

式(48)にて, $K, A$ は定数. $R=\int_{0}^{\infty} a^{\delta / 2+1} f(d) d a$. 式(36) において $L$ が $L_{0} に$ 変っただけである. したがって式(37) 〜式(42)にいたるまで $L$ の代りに $L_{0}$ を用いるだけで, 全く同じ形の式を得る.すなわち，このように巨視的不 規則応力集中分布を有する場合にもワイブル型の分布を 得ることができる.このように，本理論はいってみれば ミクロとマクロの確率的因子を結びつけた確率過程論と いってよいであろう。本理論の大きな特徴はマクロは不 規則因子を，ミクロ理論の中の $L$ (式(37)の)のような係 数項の中にとじこめてしまうことができるという点であ る.なお，破壊確率の $\delta ， a$ 依存性がき裂長さの分布関 数 $f(a)$ の関数形には無関係であること, $f(a)$ の形は $R$ の中にとじこめられてしまっているといら点で便利で ある ${ }^{44)}$. 
なお，寸法効果は $n$ を通して $(n=\rho V, V$ 容積)表われ， 破壊強度 $\sigma_{c}$ は式(41)，式(42)のどちらを用いても

$$
\sigma_{c} \propto V^{-/(\delta+1)}
$$

のようになり，ワイブル理論で説明できる問題はすべて 説明可能である。 したがって, 曲げや捩り強度と引張強 度の比などの比較は文献3)に記載してあると全く同様に 可能である. それだけではなく，本理論の特質はワイブ 儿理論では説明不可能な応力速度や温度依存性など動的 特性の説明が可能である点である。

(ii) き裂分布総数 $n$ が少ない場合：このときには式 (44)による偶然量の和の分布として調べればよい45). シ ミュレーション法を用いた計算によれば，き裂総数 $n$ の 数が 1〜10 ( $m_{i}$ の分布が $\Gamma$ 分布のとき) ないし 10〜100 ( $a$ の分布が 指数分布のとき)ぐらいに多くなればワイブ ル分布で近似される ${ }^{45)}$.

\section{1. ぜい性固体破壊のワイブル (Weibull) の 最小值確率論との比較}

ぜい性固体破壊のワイブル (Weibull) の最小值確率論 の詳細については文献 ${ }^{3) 4)}$ に記述されているので, これ

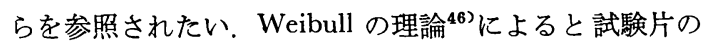
強度の確率密度関数 $g_{n}(\sigma)$ 及び 分布関数 $G_{n}(\sigma)$ はそれ
ぞれ式(50)及び式(51)のように表わされる.

$$
\begin{aligned}
& g_{n}(\sigma)=\beta m \sigma^{m-1} \exp \left(-\beta \sigma^{m}\right) \\
& G_{n}(\sigma)=1-\exp \left(-\beta \sigma^{m}\right)
\end{aligned}
$$

ここで $\beta=n d$. 式(51)が有名なワイブルの分布関数とい われるものである，また，破壊強度は，最頻値としての 破壊強度 $\sigma_{c}$ 及び平均值としての破壊強度 $\bar{\sigma}_{c}$ は，それぞ れ次式で与えられる。

$$
\begin{aligned}
& \sigma_{c}=\frac{1}{\left(\alpha_{n}\right) 1 / m}\left(\frac{m-1}{m}\right)^{1 / m} \\
& \bar{\sigma}_{c}=\frac{1}{(\alpha n) 1 / m} \Gamma\left(\frac{m+1}{m}\right)
\end{aligned}
$$

ただし，本質的な大きな仮定があることを忘れてはな らない.それはき裂の強度分布の確率密度分布関数 $f(\sigma)$ として

$$
f(\sigma)=\alpha m \sigma^{m-1} \exp \left(-\alpha \sigma^{m}\right)
$$

を仮定しているという点である. $\sigma \geqq 0, \alpha>0, m>1, \alpha, m$ は定数 ${ }^{599} . n=$ 試験片に含まれるき裂総数. $\Gamma=$ ガンマ 関数.

\begin{tabular}{|c|c|c|}
\hline & 最 小值 確 率 論 & 確 率 過 程 論 \\
\hline & $\begin{array}{l}\text { き裂強度の確率密度関数 : } \\
f\left(\sigma_{f}\right) \\
\text { き裂強度の累積分布関数 : } \\
\quad F\left(\sigma_{f}\right)=\int_{-\infty}^{\sigma_{f}} f\left(\sigma_{f}\right) d \sigma\end{array}$ & $\begin{array}{l}\text { 遷移確率 : } \mu(\sigma) \\
\mu=\phi(\sigma)=\phi(\dot{\sigma} t)\end{array}$ \\
\hline & $\begin{array}{l}\text { W. WEIBULL }{ }^{46)}(1939) \\
F\left(\sigma_{f}\right)=1-\exp \left(-\alpha \sigma_{f}^{m}\right) \\
\alpha, m=\text { const. }\end{array}$ & $\begin{array}{l}\text { T. YOKOBORI }{ }^{11), 44)}(1953,1973) \\
\mu=L \sigma^{8} \\
L \propto n^{*}, L, \delta=\text { const. } \\
n^{*}=\text { ミクロ欠陥の総数 }\end{array}$ \\
\hline $\begin{array}{l}\text { 固体破壊強度の累積 } \\
\text { 分布関数 }\end{array}$ & $\begin{array}{l}G n\left(\sigma_{f}\right)=1-\exp \left(-n \alpha \sigma_{f}^{m}\right) \\
n=\text { マクロ欠宿の総数 }\end{array}$ & $D\left(\sigma_{f}\right)=1-\exp \left[-\frac{L \sigma_{f}^{\delta+1}}{(\delta+1) \dot{\sigma}}\right]$ \\
\hline \multirow[t]{3}{*}{$\begin{array}{l}\text { 固体破壊強度の平均 } \\
\text { 値 }\end{array}$} & $\sigma_{c}=\frac{1}{(\alpha n)^{1 / m}} \Gamma\left(\frac{m+1}{m}\right)$ & $\sigma_{c}=\left[\frac{(\delta+1) \dot{\sigma}}{L}\right]^{0+1 / 1} \Gamma\left(\frac{\delta+2}{\delta+1}\right)$ \\
\hline & & 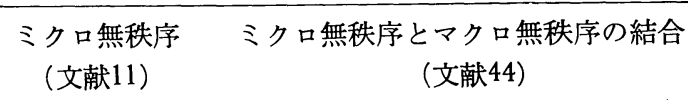 \\
\hline & & $\begin{array}{ll}L=n^{*} M, & L=n n^{*} A^{*} R \\
M=\text { 定数 } & A^{*}, R=\text { 定数 }\end{array}$ \\
\hline
\end{tabular}

最小值確率論では分布応力集中の大きさは時間的に変 化しないとし，その最大值で決まるといら考え方であ る.しかし，確率過程論では，原子の熱振動の不規則性 から，応力集中が時間的に変化すると考えていることに

表 1 固体破壊の確率過程論と最小值確率論の比較32)

$\sigma=$ 負荷応力, $\sigma_{f}=$ 破壊強度, ワイブル分布関数の母数として原著者の記号 $\mathrm{m}$ 用いてあるが遷移確率 $\mathrm{m}$ 混同しないよらに注意. 
なる．現時点で最大である集中度が破壊するまで最大の ままでいるという訳ではない。この点が基本的に相違す るのである。

それにもかかわらず，これらの結果が 9 章に述べたよ らに形式的には全く確率過程論模型の中に，その特別の 場合として含まれてしまう。しかも10章に示したように 巨視的応力集中源の分布がワイブル模型の場合のように 存在する場合でも全く同様である. 少なくとも時間依存 型破壊に対しては，最小值の確率論の模型よりも，確率 過程論による模型の方が合理的であることがわかるであ ろう。

なお，横堀らによる 9 章及び 10 章の (i) の 理 論と，

Weibull による最小值確率の理論とを比較対比すると表 1 のようになる ${ }^{32)}$.

\section{2. 材料の $\mathbf{P}-\mathbf{S}-\mathbf{N} ， \mathbf{P}-\mathbf{S}-\mathbf{t}$ 関係}

繰り返し応力振幅 $\sigma$ のもとで繰り返し数 $N$ まで破壊し ないでいる確率 $P(N)$ は，式(12)の時間 $t$ の代りに $N$ を 用いて

$$
P(N)=\exp \left(-\int_{o}^{N} \mu d N\right)
$$

で与えられる．他方， $\mu$ は $\mu \propto N^{\nu}$ なる式で近似できる ので，この式を式(55)に代入すると

$$
P(N)=\exp \left(N^{\gamma+1} / \gamma+1\right)
$$

又は $\gamma+1=m$ とおけば

$$
P(N)=\exp \left(-\alpha N^{m}\right)
$$

式(57) ${ }^{44)}$ は疲労寿命に関するワイブル表示と全く一致す る. 疲労破壊の確率過程論は特別の場合として疲労寿命 のワイブル表示を含む一般的考え方であることがわか る. 式(57) 渄破壊の確率 $P$ をパラメータとする $\mathrm{S}-\mathrm{N}$ 線図，すなわち S-N-P 線図を表わす ${ }^{47)}$ (図 8 ).

クリープ破壊や環境による遅れ破壊に対しては，繰り 返し数 $N$ の代わりに時間 $t$ を用いることにより, 式(56), 式(57)が成り立つ. 寸なわち $S-t-P$ 線図で表すことがで きる ${ }^{3)}$. な押, $\alpha$ を応力で表す研究も行われている. ${ }^{59)}$

損害の大きい場合の信頼性の立場からは破壊の確率

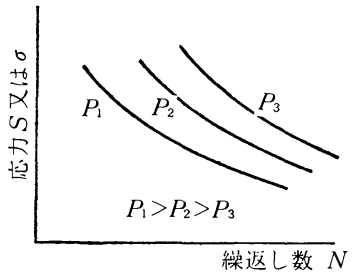

(a) $P-S-N$ 線図

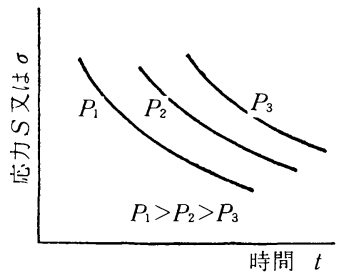

(b) $P-S-t$ 線図
図 8 時間依存型破壊の寿命-応力-確率関係線図
$P_{f}(=1-P)$ の小さい領域の $P_{f}$ 曲線の形状決定が必要で ある.そのためには大標本 (約 100 本)による実験が必要 であり，これによれば $P_{f}$ 曲線には寿命の下限界值が存 在することが示されている58)59).

\section{3. 信頼性工学としての内容}

本内容は信頼性工学そのものに他ならない.ただし従 来の信頼性工学 ${ }^{48)}$ の技法は巨視現象論であるといってよ い．逆にこれがために一般性があると考えられる。すな わち，破壊していない状態を非故障状態，破壊した状態 を故障状態に対応させているわけである（システムは修 理によってもとの状態にもどるとしている.).ここで， $R(t)$ : 信頼度 (reliability): システムが規定の条件のもと で一定の期間中，規定の機能を果たす確率. 非破 壊確率(例えば式 (12)の $P$ に相当する.)

$f(t)=-d R(t) / d t:$ システムの寿命分布，すなわち寿命の 確率密度関数

$\lambda(t)=-\frac{d R(t)}{d t} / R(t)$ : システムの故障率 (force of motali$\mathrm{ty})$ ，単位時間ないし単位繰り返し数当たり破壊の 起こる確率. 遷移確率 $(m$ 又は $\mu)$ に相当する

信頼性工学が一般性があるという最大の理由は，実は観 測データから処理して得られた $R(t)$ や $f(t)$ から式(59) にしたがって故障率 $\lambda$ を逆算しているということにある といってよい，そしてこの入を用いて確率過程論を適用 しているといら意味で現象論であると言えるであろう. すなわち，確率過程とみなせる問題は，すべてこの程度 の一般的取扱いが可能であることは寸でに述べてある 4). 問題は $\lambda$ の意味や内容が，問題の種類によってこと なるといら点なのである。しかも，材料強度や破壊のよ うな問題においてさえも，本文に述べたように反応論的 な内容をもつ場合と，そうでない場合とがあることを注 意したい. 本文の内容のらちの基本面は, 信頼性工学に おける故障物理 ${ }^{49)}$ であるといってよい，

図 3 (a)，(b)，(c) には信頼性工学の基礎として仮定さ れ，また多くの問題や場合に実験的に成り立っている寿 命の確率密度関数 $f$, 信頼度 $R$ 及び故障率 $\lambda$ をそれぞれ 示し, かつ破壊の確率過程論の場合の寿命の確率密度関 数 $q$, 非破壊の確率 (生存率) $P$ 及び破壊の確率 $\mu$ とそれ ぞれ対比させておいた.

作用する力が故障の因子に入り込む場合，特に材料強 度や破壊の問題においては熱活性化過程(速度過程)に従 う降伏, ぜい性破壞, 疲労に対して遷移確率 $m$ 又は $\mu$ は 式(60)で与えられる1). 
$m$ 又は $\mu=A \exp \left[-\left\{U_{0}-\Phi\left(\sigma_{l}\right)\right\} / k T\right]$

ここで, $\sigma:$ 公称応力, $\sigma_{l}$ : 局所応力 $=q_{1} q_{2} \sigma, q_{1}, q_{2}$ はそ れぞれマク口及びミクロ応力集中, $q_{1} \sigma:$ 応力桩大係数 $K$ に相当するものであって, $q_{1} \sigma=\beta K$ なる関係にある ${ }^{50)}$. $U_{0}$ : 活性化エネルギー, $T$ : 絶対温度. これら機構の異 なるきわめて多種類の破損 (不連続)現象の場合に一一例

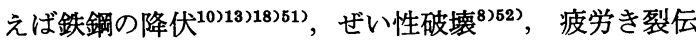
播(き裂核生成論模型 ${ }^{24)}$ ，空孔拡散模型 ${ }^{53)}$ ，転位群動力 学模型 ${ }^{29) ~ 31)}$ ) などについて一一共通して式(60)における 力 (応力)の影響を表す関数 $\Phi$ は

$$
\Phi=v \ln \sigma_{l}
$$

のように与えられる ${ }^{14)}$. ここで $v$ は定数. すなわち，力 の影響は次のような簡単な形で表されることが示されて (る1)4.

$$
\Psi \equiv \Phi / k T \equiv \delta^{*} \cdot \ln \sigma_{l}=\delta^{*} \cdot \ln \left(q^{*} \sigma\right)
$$

ここで $q^{*}$ : 局所応力集中 $q_{1} q_{2}, \delta:$ 材料，寸法及び温度な どの環境条件による定数， $\Psi$ を力関数と呼んでおく，遷 移確率 $m$ 又は $\mu$ 又は故障率 $\lambda$ は式 $(60)$ のように $\Psi$ につい ての増加型指数関数に比例する。すなわち，

$$
m \text { 又は } \mu \text { 又は } \lambda \propto \exp (+\Psi)
$$

で表されるから，式(63) と式(62)から

$$
m, \mu \text { 又は } \lambda=B_{1} e^{\Psi}=B_{1} \sigma_{l}{ }^{\delta *}
$$

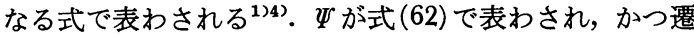

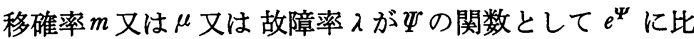
例するとして表されることから， $m, \mu$ 又は $\lambda=B_{1} \sigma_{l}{ }^{\delta *}$ の 形で表わされるのであり，このために，力の作用のもと

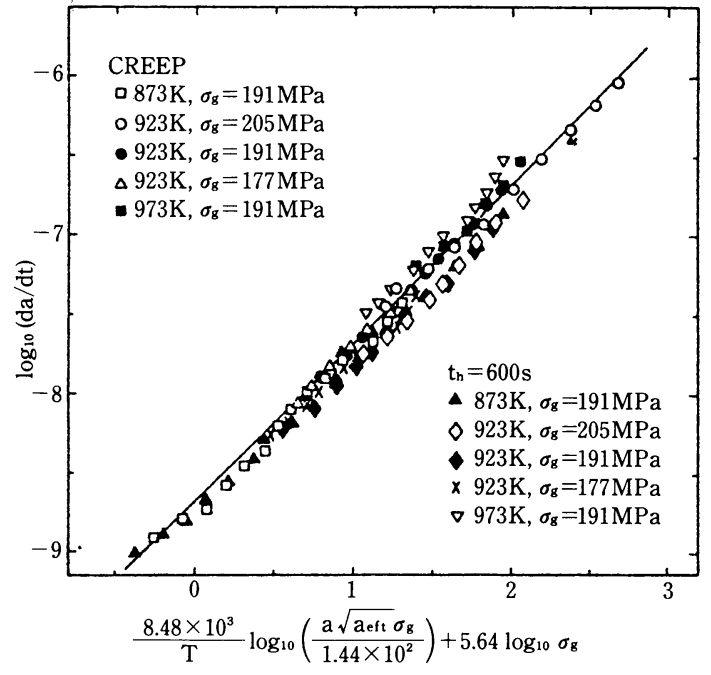

図 9 高温クリープ，疲労及びクリープ・疲労重畳 でのき裂成長速度のパラメータ表示式 ${ }^{54}$ (304ステンレス鋼) 実線は理論式による.
での材料破損や信頼性工学の確率論的解析を極めて容易 としている1)4.

\section{4. 高温におけるクリープ，疲労及びクリー}

\section{プ・疲労の重量による破損の比較研究}

高温下でのクリープ, 疲労及びクリープ・疲労の重曽 の場合のき裂進展速度を破壊力学因子など独立 パラメ

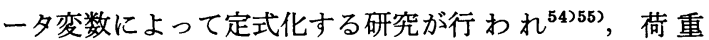
(応力), き裂長さ, 温度などの独立変数による表示式が 提案さ礼 ${ }^{5455)(0)}$ ，き裂成長速度の予知に有効であろう (困 9 ).

\section{5. 応力腐食割れ，腐食疲労及びその重畳に よる破損の比較研究}

応力腐食割れ，腐食疲労及びその重畳による破損の比 較研究 56)57) は，14章における研究の腐食環境下での研究 に相当するものと言える.この研究によって，寿命則 ${ }^{56)}$ のほか, 荷重(応力) 波形効果や繰り返し速度効果 ${ }^{36) 57)}$ が 調べられている，14章や15章のような比較研究方法論が 重要である.

\section{6. む す び}

以上，金属材料を主な例にとって，破損寿命問題につ いて最近の研究及びその体系化への努力について述べ た. ワイブル 関数との関係，Pfの小さい領域の寿命推 定法，ワイブル確率紙との関係などについては別に発表 の予定である ${ }^{59)}$. 破損寿命といった複雑な問題の解決は 学際 的一異 材料学(いずれも産学を含む) 共同研究によら ねばならないことを附言したい.

\section{参考 文 献}

1) 横堀武夫：材料強度学 (岩波全書) (1974)(Russian Edition, Naukava dumka, Kiev. (1978))

2) 平田森三：応用統計学 11，16，金原書店 (1949); 機械の研究 1 (1949) 231，統計数理研究 3 (1949) 47

3）横堀武夫：材料強度学，技報堂（1955) (English Edition; Strength, Fracture \& Fatigue of Materials, Wolters-Noordhoff. Co., (1965)) Groningen, The Neetherlands.

4) 横堀武夫：材料強度学, 岩波全書第 1 版 (1964) (English Edition; T. Yokobori, An Interdisciplinary Approach to Fracture \& Strength of Solids, Wolters-Noordhoff Ltd. (1968))

5) 横堀武夫 : 東大理工研報告 3, No. 5-6 p. 193 (1949); 機械学会第27期総会講演 (1950年 4 月 8 
日); T. Yokobori: J. Phys. Soc. Japan 681 (195I)

6) T. Yokobori: J. Phys. Soc. Japan 6-2, 78 (1951)

7) T. Yokobori: 同上誌 7, 122 (1952)

8) T. Yokobori: 同上誌 7-1, 44 (1952)

9) T. Yokobori: 同上誌 7-1, 48 (1952)

10) T. Yokobori: Phys. Rev. 88-6, 1423 (1952)

11) $Г$. Yokobori: J. Phys. Soc. Japan 8-1, 104 (1953)

12) T. Yokobori: 同上誌 8-2, 265 (1953)

13) T. Yokobori: J. Appl. Phys. 25-2, 593 (1954)

14) T. Yokobori: J. Chem. Phys. 22-5, (1954) 951

15） T. Yokobori：東大理工研報告（英文） 8-1，5 (1954)

16) T. Yokobori: J. Phys. Soc. Japan 10-5, 368 (1955)

17) T. Yokobori and H. Ohara: 同上誌 13-3, 305 (1958)

18) T. Yokobori: Kolloid-Zeits 166-1, 20 (1959)

19) B. D. Coleman: J. Appl. Phys. 27, 862 (1956)

20) B. D. Coleman: J. Appl. Phys. 29, 968 (1958)

21) M. Hori: J. Phys. Soc. Japan 14, 1444 (1959)

22) a) 横堀, 笹平: 日本材料強度学会誌 2 , No. 4 p. 40 (1967)

b) 横堀：材料 20,453 (1971)

c) 横堀: 日本材料強度学会誌, 医用生体機 材特集号 15, No. 3 p. 1 (1980)

23) D. Prevorsek and J. W. Lyons: J. Appl. Phys. 35, p. 3152 (1964)

24) T. Yokobori: Physics of Strength and Plasticity, A. S. Argon Ed., MIT Press (1969) 327. 一部は横堀武夫：日本材料強度 学 会誌 3-1, 1 (1968)

25) T. Yokobori and M. Ichikawa: Rep. Res. Inst. Str. \& Frac. Master. Tohoku Univ. 4, 45；(1968) 日本材料強度学会誌 4，1 (1969)

26) T. Yokobori: Rep. Res. Inst. Str. \& Frac. Mater. Tohoku Univ. 5, 19 (1969)

27) T. Yokobori and M. Yoshida: ibid. 7, 49 (1971)

28) T. Yokobori and M. Ichikawa: ibid. 6, 75 (1970)

29) T. Yokobori, A. T. Yokobori, Jr. and A. Kamei: Int. J. Fracture, 11, No. 5 (1975)p. 781; Ibid, 12, No. 4, p. 519 (1976)

30) 横堀武夫 : 横堀寿光 : 日本 金 属 学 会 誌 42 , No. 1, p. 88 (1978)

31) T. Yokobori, S. Konosu and A. T. Yokobori: Proc. ICF 4, Pergamon Press, Vol. 1, p. 665 (1977)

32) T. Yokobori: Proc. 5th Int. Conf. Fracture, Vol. 3, p. 1145 (1981)
33）横堀武夫 : 1949年の実験

34) L. F. Coffin, Jr.: Proc. 2nd Int. Conf. Fracture, Chapman and Hall, p. 643 (1969)

35) T. Yokobori, M. Kawagishi and T. Yoshimura: 同上 p. 803

36) 横堀武夫, 横堀寿光 : 第 27 回材料強度と破壊 国内シンポジウム論文集 27, p. 29 (1982)

37) A. T. Yokobori, Jr. \& T. Yokobori: Proc. 5th Int. Conf. Fracture 3, p. 1373 (1981)

38) A. T. Yokobori, Jr. \& T. Yokobori: Fatigue Thresholds, Engineering Materials Advisory Services Ltd., Warley, U. K. p. 171 (1982) 横堀 寿光，横堀武夫：材料 31，488 (1982)

39) E. Strecker, D. A. Ryder \& T. J. Davies: J. Iron \& Steel Inst. 207, 1639 (1969)

40）柴田俊夫 : 第 25 回強度と破壊シンポジウム論 文集, p. 1, 日本材料強度学会他関連学協会 (1980)

41) T. Yokobori \& T. Kawasaki: Rep. Res. Inst. Str. \& Fract. Mat. Tohoku Univ. Sendai，Japan 6，69；(1970）一部は強度と破壊 第16回国内シンポジウム論文集 (1971) 129

42）横堀武夫，北川正義：日本機械学会論文集 45, No. 346, p. 1650 (1975)

43）安藤 桂，小倉信和，大橋正幸：日本材料強 度学会講演論文集 41 (1973)

44）横堀武夫, 沢木洋三：日本材料強度学会誌 6-4 (1972) 109, Int. J. Fract. 9, 95 (1973)

45) 横堀武夫, 市川昌弘, 藤田文夫 : 日本機械学 会論文集 111 (1974)

46) W. Weibull: Ing. Vetenskaps Akad. Handl. No. 151 (1939); No. 153 (1939)

47) W. Weibull: Trans. Roy. Inst. Tech. Stockholm, No. 27 (1949)

48）たとえば, E. Piervshka, Principles of Reliability, Prentice-Hall (1963)

49) 塩見 弘: 故障物理入門, 日科技連 (1972)

50）横堀武夫：機械の研究 27, No. 7, p. 803 (1977)

51) A. 'T. Yokobori, T. Kawasaki \& T. Yokobori: High Velocity Detormation of Solids, IUTAM Symposium, Springer Verlag, p. 132 (1979)

横堀寿光，横堀武夫，川崎正 : 日本機械 学会論 文集 45, No. 395, p. 760 (1979)

52) T. Yokobori \& M. Kitagawa: Proc. SemiInt. Symposium on Experimental Mechamics Vol. II Japan Soc. Mech. Ergrs. p. 183 (1967)

53) T. Yokobori \& M. Ichikawa: Rep. Res. Inst. Str. Frac. Mats. Tohoku Univ., 6, No. 2, p. $75(1970)$

54) T. Yokobori, H. Sakata \& A. T. Yokobori, Jr.: Engng, Fract. Mech., 13, 533 (1979)

55) T. Yokobori, A. T. Yokobori, Jr., H. Sakata \& I. Maekawa: Proc. IUTAM Symp. Three- 
dimensional Constitutive Relationship and Ductile Fracture, Dourdan, North-Holland Pub. Co., 365 (1981)

56）横堀武夫，桑野博喜，滝沢英樹：日本機械学 会論文集，A. 47, 419689 (1981)

57) 横堀寿光, 横堀武夫, 高須展夫 : 日本機械学 会講演論文集 No. 820-2 p. 167, (1982) No. 830 -2 (1983)

58）横堀武夫，横堀寿光，淡路英夫 : 日本機械学 会第60期総会講演論文集，No. 830-2 (1983)

59）横堀武夫, 淡路英夫, 横堀寿光 : 第28回材料 強度と破壊国内総合 シンポジウム論 文 集, 28
(1983)，ワイブル関数を確率過程論において特 別の場合として遷移確率として用いることがで きる. 確率過程論的 取扱いでも ワイブル確率紙 を用いると便利なのはこのためである。なお， 強度でなく寿命に関する限りはワイブル母数 $\mathrm{m}$ はミでもよい.ただし $\mathrm{m}<1$ の場合は，時間な いし繰返し数とともに遷移確率が減少していく ということになる。

60) A.T. Yokodori, Jr.T. Yokodori, H. Tomizawa \& H. Sakata:J. Engng. Materisls and Technol, ASME. (1983)

\title{
新刊紹介
}

\section{自動車材料ハンドブック〈プラスチック編〉}

\author{
B 5 判 本文 240 ページ \\ 監修 神 原周 \\ 定価 4,800円 送料 300 円
}

我が国の自動車生産台数は，1980年に1，104万台とアメリカの801万台を抜いて，ついに世界第 1 位と なった. これは1973年以降の 2 度にわたるオイルショックによって石油価格が高騰したため, 然費効率 のよい車の需要が世界的に急増したことによる，一方，日米，日欧の経済摩擦が激化するなかで，我が 国の自動車産業は省資源, 省エネルギーをいかに達成するか, この課題の鍵を握るのが材料である. 本 書は，材料転換，軽量化，複合化などその実際について探究している．材料転換の主役ともいうべきプ ラスチック材料を中心に，あらゆる角度から，特に自動車用材料として要求される特性（用途，グレー ド, 物性比較, 劣化など）をデータベースとしてまとめ, 材料の評価と今後の技術的課題を探った. 更 にディスカッション，インタビューにおいて材料の動向を，材料の周辺において，デザインコンセプト， 接着，リサイクルから自動車の設計思想を考え，軽量化問題を中心とした材料の現状についてわかりや すく解説されている. 座右の書として是非一読をお奨めしたい.

\section{問合せ先 104 東京都中央区京橋 2-7-12 \\ 株式会社 大成社出版部 \\ 電話 03-561-0246}

